\title{
Using Young Adult (YA) Literature in a Classroom: How Does YA Literature Impact Writing Literacies?
}

\author{
Alice Hays \\ Arizona State University
}

While English teachers are working to incorporate various versions of the Common Core State Standards into their curriculum, they are often emphasizing canonical fiction over alternative literature that students may connect with at a higher engagement level. Young Adult (YA) literature may help teachers meet the needs of the whole student as well as local standards. The purposes of this study were (1) to explore how students engaged with reading and writing after reading YA literature, (2) to evaluate whether the YA students' writing samples differed from the canonical group's, (3) to determine if students see themselves as better writers after the experience, and (4) to examine the teacher's perception of reading YA Literature. The research was conducted in a single teacher's $9^{\text {h }}$ grade classes at an urban high school in the Southwest with a primarily Hispanic population. Two groups worked with canonical literature, and two groups worked with YA literature. All students were given a modified version of the Daly Miller Writing Apprehension Survey before and after they read either a YA short story or a classic short story. They then constructed a writing sample using the same generic prompt for all groups. Several students and the teacher were interviewed after the process. Quantitative results showed that students who read the YA pieces increased their mean score on the modified Daly Miller Survey. Their writing samples had a greater mean score than the canonical group. The qualitative results also indicated greater engagement and understanding of the $Y A$ literature, while the teacher expressed enjoyment in teaching both pieces since they were both received well by the students. Finding that students improved in a quantifiable way after using YA literature indicates that there are pedagogical reasons to incorporate $Y A$ literature in the classroom, in addition to enhancing enjoyment.

\section{INTRODUCTION}

The introduction of reforms, including the Common Core State Standards (CCSS) has resulted in a push to incorporate more rigorous or challenging reading material within classrooms. This rigor takes the form of higher levels of text complexity, in addition to emphases on non-fiction or 
canonical fiction. (Alsup, 2013; Applebee, Langer, Nystrand, \& Gamoran, 2003; Goering \& Connors, 2014; Langer, 2013). This push, coupled with the CCSS emphasis on textual references in writing seems to imply that more rigorous reading will result in more intellectual gains, often measured by writing assessments. Accordingly, several scholars explored the way students learn, and more specifically the relationship between writing and reading (Langer, 1986, 2013), as well as how the teaching of various types of literature support student learning in writing and reading (Lesesne, 2007; Alsup, 2013). One type of literature that can support these goals of meeting CCSS standards of rigor is Young Adult (YA) literature; however, YA literature is often discounted for being more accessible or "easy” than canonical works (Hayn, Kaplan, \& Nolen, 2016; Stotsky, 2010). This calls for a look at whether or not YA can produce equal or even greater educational benefits than works from the canon.

The effects of YA Literature on secondary students are fairly well understood as having a positive impact on a student's sense of value and self-efficacy (Monroe, 2005; Pajares, 2003). However, studies in which researchers discuss the impact of YA Literature on writing practices in the secondary English classroom are otherwise scarce (J. Hayn et al., 2016; Judith a. Hayn, Kaplan, \& Nolen, 2011; Malo-Juvera, 2014). In addition, those studies that do exist are inconclusive as to whether or not YA literature positively impacts students' writing proficiency (Applebee et al., 2003). While research has been conducted which demonstrates higher levels of performance when engaging classrooms in discussions, regardless of literature type, further work needs to be done in order to isolate the impact of YA literature, in particular, on pedagogical practices (Applebee et al., 2003). Over the past decade, as the tensions over education increase, a growing number of scholars are heeding this call as evidenced by journals dedicated to YA literature such as The ALAN Review, Journal of Adolescent and Adult Literacy, SIGNAL, and most recently, Study and Scrutiny. According to Hayn (2016), various research projects have been completed or are under way that explore how YA literature might address perceptions of Internet safety, perceptions of second language learners, inclusion of all students, reactions to people with physical deformities, bullying, and LGBTQ issues. Additionally, there has been a push regarding the use of YA literature to encourage social activism or citizenship (Glenn, Ginsberg, Gaffey, Lund, \& Meagher, 2012; Stover \& Bach, 2011; Wolk, 2009). While evidence does exist that supports the efficacy of YA literature in the classroom, there is still a need to conduct research that explores the potential 
for YA to provide a solid venue for the types of skills teachers feel pressured to teach in their classrooms through movements like CCSS (Goering \& Connors, 2014; J. Hayn et al., 2016)

This deficit indicates that the impact of YA literature in the classroom is, indeed, a topic worthy of study (Beumer Johnson, 2011; Hayn et al., 2011; Malo-Juvera, 2014; Thompson, 2014). Likewise, with the current push toward using non-fiction and fiction texts with Lexile scores above students' reading ability in the secondary English classroom (Kober \& Retner, 2011; Shanahan \& Duffett, 2013; Stotsky, 2014), the aim of this study is to push back against this quantitative way of valuing literature by demonstrating the potential impact of reading YA literature on writing (Alsup, 2013; Langer, 2013).

\section{LITERATURE REVIEW}

An examination of the research which addresses YA literature reveals that general themes focus upon the way literacy is changing within the classroom and the way students participate with those literacies, the benefits of reading/studying YA literature in the classroom, the resistance to YA literature, and finally the possibilities of utilizing this relatively new form of literature in the classroom.

\section{CHANGING LITERACIES}

Literacy is defined by the New Literacy Studies as something people do--not inside their heads, but inside society (Gee, 2010). Gee (2010) goes on to discuss the idea that "literacy is a social and cultural achievement... not just a mental achievement” (p. 166). As such, the way that students participate in various literacies is significantly different now as compared to the ways that students participated in the act of reading and writing in previous decades with the changing societal and cultural norms. Educators are oft-heard quoting Bob Dylan's canonical line, which certainly applies here: “the times, they are a' changing” (Alvermann, 2007; Lesesne, 2007)

Because of the growing pressure to meet proficiency levels on standardized test scores, student needs, both academically and emotionally, are often unmet in the English classroom. Our adolescents live in a tumultuous world that they are constantly "reading," and these students need a safe place to talk about what they are discovering (Appleman, 2007). When students have that safe place and are able to actively engage in discussion they find meaningful, their knowledge retention increases (Applebee et al., 2003). Therefore, it is important that English teachers create time and 
safe spaces in their classrooms to pursue particular areas of interest to students, as this may result in a focus on literature more relevant to the students. Along with relevance, might come increased learning in multiple ways (Alvermann, 2007; Beers, 2007; Ivey \& Broaddus, 2001; Keene, 2007).

\section{BENEFITS OF READING YA LITERATURE BEYOND ENGAGEMENT}

The use of YA literature in the curriculum not only values teens as individuals, but also provides teens with experiences that allow them to grow in multiple capacities, including critically engaging with YA literature to not only incorporate the literacy practices they already use but also further develop their academic literacy practices (Moore, Bean, Birdyshaw, \& Rycik, 1999). As Sam Houston State University YA literature professor Teri Lesesne argues, contemporary YA literature requires students to respond to these texts both critically as well as personally (2007). By reading YA literature, students may also realize increased capacities to find meaning in any book through the developed ability to see their own life experiences within the texts they read (Appleman, 2007). On its own, simply reading YA literature will not suddenly create better readers, but reading YA literature should help students to "create and re-create fresh...opportunities to make discoveries about texts, about language, about the world, and about themselves” (Appleman, 2007, p. 147).

One powerful example of how YA literature can have a real-world impact on student learning was demonstrated in the results of a study described in the article "Speak: The Effect of Literary Instruction on Adolescents' Rape Myth Acceptance” by Victor Malo-Juvera (2014). This study explored the significant decrease in rape myth acceptance by a group of middle school students who read Speak, a book about a date rape, as a class. Their discussion gave students who read the book a shared experience and an opportunity to discuss something that is typically a taboo subject for a classroom (Malo-Juvera, 2014). As evidenced by this study, reading Anderson's YA novel in class, and discussing it, had a more positive effect on the attitude of boys about whether girls were somehow complicit in the rape rather than victimized as compared to a class based on rape education with no fiction reading experience (Malo-Juvera, 2014). In other words, it seems that students who live these real-world experiences vicariously through reading YA novels are able to experience the cognitive and emotional growth associated with experiencing these problematic situations in a way that does not bring them physical harm.

The power of YA reading to create significant change in students' thought processes may

be harnessed for writing instruction, as well. In another example, Monroe (2005) hypothesized that 
students might be able to use YA literature as a way to find their voice. Monroe posited the idea that students may also be able to use YA literature as mentor texts that utilize language that is more familiar to the student. This might allow them to see, and emulate, an authentic voice. While Monroe cites additional authors and educators who support the idea that YA literature can be taught in a way that will support the whole student in many ways, including their approach to writing, no empirical study exists that explores this connection.

\section{RESISTANCE TO READING YA LITERATURE}

Although there are positive benefits to be realized by adolescents who are exposed to YA literature, as mentioned, there are also many forms of resistance. Interestingly enough, one of the most powerful adversaries against the implementation of YA literature is the classroom teacher. Often, teachers will self-censor in terms of the types of literatures they select to instruct their students in reading and writing because they are unwilling to fight the battles that they foresee, and see as inevitable when it comes to the anticipated resistance from school district school board members, administrators, and/or parents (Hinton \& Rodriguez, 2014; Lewis \& Durand, 2014).

As Freedman and Johnson (2000) state, however, "[t]his teacher self-censorship of literature for early adolescents deprives these students of opportunities for conversation and discovery at a crucial stage of their development” (356). Angelotti (1984) also pinpointed ignorance, fear, snobbery, and rigidity as reasons why teachers and/or curriculum directors also do not actively implement the use of YA literature in their classrooms. Unfortunately, this fear that YA literature is not "literary" enough or will incite the parents continues today (Hayn et al., 2016). Some of this may result from an over-emphasis on text complexity; however, several scholars have demonstrated YAL's ability to support for rigorous instruction (Bickmore \& Emiraliyeva-Pitre, 2013; Connors, 2012). This belief that YA literature is insufficient in some way is further elucidated in the idea that many teachers lack the language or even beliefs to defend the YA literature they might be interested in teaching in the secondary English classroom. Due to a lack of critical theory surrounding YA literature or societal acceptance of the academic rigor of these types of writing, teachers, then, continue to avoid this type of literature (Hunt, 1996; Lesesne, 2007; Thompson, 2014).

The reasons behind this avoidance can be addressed, however. When teachers were asked to analyze a variety of texts, including both canonical and YA literature, Thompson (2014) 
discovered that the teachers found many intellectually stimulating ideas to discuss in both types of literature, beyond the thematic elements so often touted as YA literature's sole appeal. Accordingly, given this rich quality of text there also lies a rich opportunity to write.

\section{The Possibilities}

The impact of reading YA literature on writing ability, as noted, has not been tested and proven. Hence, conducting a mixed-method study to investigate these relationships further might serve to assess whether the use of YA literature in the classroom is a viable way to meet current standards (e.g. Common Core State Standards), while simultaneously meeting and addressing the needs of the whole student. Malo-Juvera (2014) stated it quite eloquently when he wrote:

Unfortunately, current educational reforms promote a continued narrowing of the curriculum that marginalizes or eliminates instruction like that featured in [his YA literature] study. The onus is on educators and researchers to continue to argue for instruction that not only teaches testable concepts, but also addresses issues that could be relevant for many of today's youth. (p. 422)

Relevance, here, is the term to be underscored. One way to introduce students to the specialized discourses (Cazden, Cope, Fairclough, Gee et al., 1996) necessary in today's academic world is by helping them participate effectively in the conversations within their society, within their safe places, and by providing reading relevant to the lives they live. This may be done through literature to which they already have access (Applebee et al., 2003), but which they do not necessarily read given the constraints above, as well as others. In addition, the lack of wide-spread research that supports the study of YA literature in order to validate the individual students' experiences, provide mentor text opportunities for writing, and support engagement of critical literacy as examples, may wrongly keep YA literature out of every day students' reach (Appleman, 2007; Burke, 2007; Lesesne, 2007; Monroe, 2005; Pajares, 2003). The goal of this study, then, is to examine the effects of YA literature on writing in the classroom.

\section{Purpose of Study}

The purpose of this study was to evaluate the intersection of reading YA literature and writing in the classroom in order to discover whether the utilization of YA literature positively impacted literacy acts, as demonstrated via students' attitudes, students' writing products, and students' 
discussion surrounding the use of YA literature to support writing. The four research questions the study addressed included: (1) in what ways do students who engage with YA literature have different classroom experiences reading and writing than students who engage with the canon? (2) in what ways do students' writing samples demonstrate that students writing about YA literature produce higher quality writing in terms of voice, elaboration and analysis than those working with the canon? (3) what are students' perceptions of their reading and writing abilities after engaging with YA literature? and (4) what is the teacher's perception of students' experience with YA literature?

\section{Methods}

To answer these research questions, this mixed-methods study (Creswell \& Clark, 2010) looked at quantitative measures of writing as well as qualitative measures of student and teacher experience in order to inform each research question. More specifically, this study measured the impact of YA literature on students, specifically their attitudes about their writing and themselves as writers as well as the quality of their writing by using student self-report assessments, student writing samples, and student interviews. Teacher interviews were also employed following the implementation of these instruments. Although a number of limitations restrict the power of findings within this study, the empirical data warrant further research into the study's premises.

\section{PARTICIPANT SAMPLE}

One urban high school from the Southwest was selected for this study although several schools from various districts were approached. The topic of this study, the use and impact of using YA literature, was problematic in that YA literatures were not to be found on potential districts' approved reading lists. Several teachers were hesitant to teach titles that were not already accepted. Luckily, however, one school's English curriculum director thought this study would be beneficial for her school and suggested approaching the ninth grade English team at her high school.

The district in which this school is located is the oldest district in the state and serves 27,000 students with a total of 16 high schools. The district covers 220 square miles, so it is fairly extensive, both geographically and demographically. This school serves students from financially insecure backgrounds with $91 \%$ of the student population being eligible for free-and-reduced lunches. The demographics of the school are $94 \%$ Hispanic, $3 \%$ black, and $2 \%$ white. There are a 
total of 2,043 students in the school. In addition, the state ranks schools with grades depending upon their scores on the state standardized test and how much each school improves from year to year, and this school moved from a $\mathrm{C}$ grade to a $\mathrm{B}$ grade in the year 2014, making this school one of the top eight of the 16 within the district. The district as a whole has a $\mathrm{C}$ grade.

At first, three out of six $9^{\text {th }}$ grade teachers expressed interest in participating in the study. Time constraints and the teachers' instructional calendars dictated that only one teacher's classes were available for the study, thus limiting the sample size. The participating teacher was the leader of the $9^{\text {th }}$ grade team and was ready to implement the lesson within the desired time frame, which was the first half of the second semester, and we were limited to a single week for the instruction. Working with a single teacher facilitated keeping the "teacher effect" constant, allowing better isolation of the impact of YA literature on the students' writing without confounding variables introduced because of variance across teachers. The teacher, Sandy, a pseudonym, is a soft-spoken lover of Shakespeare and a self-proclaimed “nerd." She is Caucasian, which separates her from her students on one level, although she is quick to smile at the students and appears to have a generally good rapport with them.

Sandy has six years of experience at this school, and four of her six classes were ninth grade English. In these four classes, Sandy had a total of 109 students; hence, it was these 109 students across these four classes who were potentially available for this study. Within these four classes, however, one class had a relatively high concentration of special education students, with nine out of 24 students $(37.5 \%)$ in special education programming. There was also a resource teacher who came to that class every day to support these students. Another of Sandy's classes was described as slightly below average, the third was average, and the fourth was described as being above average according to the teacher's relative comparison. To encourage Sandy's complete commitment to the study, she was allowed to choose which classes would read which piece. Due to her own preconceptions that YA literature would be more accessible to struggling students (Goering \& Connors, 2014), she chose to have the class with the higher concentration of special education students and the class she defined as slightly below average read the YA story. The other two classes (average and above average) read the canonical short story. This meant there were two treatment (YA) groups of students the teacher considered to be below average and two control (canonical) groups of students considered to be above average by the teacher. While this lack of heterogeneity across the sample must be considered a limitation in the sense that these groups are 
not comparable, another possibility was that the different students might have engaged differently with the YA texts, particularly the groups of students considered below average. For this reason, the results of the treatment must be interpreted with this in mind

Both canonical groups read "Harrison Bergeron" (Vonnegut, 1961) a classic short story, while both YA groups read the short story version of "The Last Book in the Universe" (Philbrick, 1999) found in Tomorrowland (Cart, 1999). Both stories are dystopian literature where external forces control the main character, and there is also an over-dependence upon outside technology throughout both pieces. In Philbrick's story, the protagonist is unable to insert and use the electric mind probes utilized by his peers due to epilepsy, which causes him to experience the world differently. While going through the ritualistic behaviors necessary to become part of a local gang, he attempts to rob an old man called "Ryter" and becomes intrigued by the writing on paper that this man seems to value above everything else. Over time, the protagonist befriends the man and begins to learn how to read. His peers, however, are brutal and unfeeling, and the story concludes with Ryter being dragged through the streets while onlookers cheer, and our protagonist begins a new life of trying to continue Ryter's efforts to capture events on paper through words (Cart, 1999).

Vonnegut's "Harrison Bergeron" centers on a couple whose thoughts, strengths, and even physical appearances, are controlled by a handicapper general (a government employee who assigns various 'handicaps' such as extra weight, thought interrupters or masks to those deemed above average in the relevant categories) in the name of equality. This particular couple has a son who is able to rebel against the system; however, his existence is virtually wiped from their mind due to the devices used to prevent their ability to think clearly. The handicapper general shoots their son on television, and the parents are unable to even remember the event moments after they witness his murder (Vonnegut, 1961).

The stories were both read during class time, using the close reading strategies they had been accustomed to doing. These strategies included identifying and circling unfamiliar vocabulary words, highlighting unclear phrases or ideas and boxing names and places that they encountered. The teacher spent the first reading day having the class review vocabulary words she had identified as potentially problematic. The students were asked to look those words up in the dictionary, and write the definitions down on a separate piece of paper. As there were slang words incorporated into the story, the teacher also discussed using context clues to understand those words. After a brief period, we realized that the students were only circling the vocabulary words previously 
identified by the teacher, and Sandy reminded the students to circle all unfamiliar vocabulary words. After this initial 15 minutes of vocabulary work, the students got into small groups and continued reading on their own. There was little classroom discussion at that point. The reading itself took four class periods. Immediately upon completing the stories, the teacher expressed that she was feeling pressured to get back to her original instructional plans, so she had the students take the post-test surveys and complete the writing prompt with no further activity with the story.

\section{DATA COLLECTION}

First, an inventory instrument entitled a "Student Self-Report Survey" was used to assess the attitudes the students had towards writing as an act, both before and after reading either story above, as per whether students were in the YA or the canonical groups, respectively. The goal here was to get at an understanding of how the students felt about their writing and whether they may have felt their writing was different after reading a YA literature piece versus one that was not. This inventory instrument was a modified version of the well-vetted Daly-Miller writing apprehension survey (Daly \& Miller, 1975), employing changes from the original instrument in terms of some of the word choices in order to make sure students understood what was being asked (e.g. changing composition to writing where appropriate). Higher levels of writing apprehension are connected to poor performance on situational writing tasks, and this instrument has been commonly used in order to ascertain students levels of apprehension(Daly \& Wilson, 2016; Daly \& Miller, 1975; Daly, 1978). On the original instrument, there were 26 Likert-type items meant to ascertain students' levels of "writing apprehension” explained by Daly (1978) as “...a situation and subjectspecific individual difference concerned with people's general tendencies to approach or avoid writing”(p. 10). The survey also includes seven demographic items meant to find out more about students and how they fit into the school's general demographic along with their familiarity with the language used in the classroom (e.g., What is the language most often spoken at home?). Students completed this survey before they began reading their assigned literatures, and after. All 109 students in the four classes were to take the survey, and students who were absent were to take the survey upon their return to class; however, there were twenty-one students who were ultimately removed from the study due to missing one of the two survey responses. (See the "Self-Report Survey" in Appendix A.) 
Second, students in all four classes participated in a writing exercise, which yielded a writing sample used to assess whether the type of reading in which students engaged actually impacted their writing quality in different ways, again as per the YA and canonical groups. More specifically, all four classes of students were asked to write about the impact of technology on humanity, the common thread or theme of both the stories. As per the Common Core's increased emphasis on text-based evidence, students were explicitly asked to reference the story they read when making supporting claims. This was done to help ascertain, again as per the "text-based evidence" issue, if the writing itself guided students' argumentation or if their essays were based primarily on prior knowledge and personal experience. Otherwise, the teacher guided the students through the other typical pre-writing activities that students were already accustomed to before writing any assignment, so this too was held constant. This also included a class discussion about the story. Thereafter, students were to spend most of one class period on these writing pieces, writing three to five paragraphs on the topic, as also commonly expected as per similar assignments in their class. (See the "Student Writing Prompt" in Appendix B.)

Semi-structured student interviews were conducted with 12 selected students from both classes, six from the canonical groups and six from the YA groups, to get a more descriptive picture of how the students felt both about either piece of literature they read but also their ability to complete the writing assignment after reading the story. Ten questions were employed (See "Student Interview Protocol" in Appendix C.). The students selected to be interviewed were those who demonstrated the largest positive growth on the "Student Self Report" survey from pretest to posttest in order to further investigate the nature of their experience with richer, detailed information. Unfortunately, however, due to missing students, three of the interviewees were not those who showed the largest growth from their pre survey to their post survey, and were instead chosen by the teacher as being students who were excited to be interviewed. While my initial goal of purposively sampling these students was to isolate the factors influencing the change in "SelfReport" score, having students who volunteered to be interviewed ultimately resulted in richer, albeit perhaps less representative data. Accordingly, the use of more of an opportunistic sampling approach (Ritchie, Lewis, \& Elam, 2003) did indeed result in a richer data set, which afforded me what I believed to be a more enlightening view of the students' experiences.

Finally, one teacher interview was conducted to discover and better understand the teacher's perspective throughout this study, and more importantly, to explore whether the teacher 
noticed anything different between the classes based upon the different literatures (i.e., YA and canonical stories) they read. Eight questions were used (See "Teacher Interview Protocol" in Appendix D.). The interview was conducted face-to-face after the entire process was complete, in order to get a full understanding of the classroom teacher's perceptual experiences, as well.

\section{DATA ANALYSIS}

Changes in students' responses from the pre to the post-test on the "Student Self-Report Survey" (see Appendix A) were analyzed to discover students' overall attitudes towards writing and to examine differences in students' attitudes as per their story affiliations. This was done by analyzing mean gains (along with standard deviations) from pre- to post-test and then comparing these means across groups using independent samples t-tests for statistical significant differences in between. Overall, the study's hypothesis here was that students who read the YA story would end up feeling less apprehension towards writing, per the "Student Self Report," than students who read the classic short story.

To make sure this instrument was also functioning as intended, especially as it is based on the Daly-Miller Writing Apprehension Survey (Daly \& Miller, 1975), an internal-consistency analysis, yielding Cronbach alphas (Cronbach, 1951) was employed to make sure that there was reliability within and between the student responses within the instrument (Gliem \& Gliem, 2003). For all items where positive statement values (PSVs) were anticipated, $\alpha=0.87$. For all items where negative statement values (NSVs) were anticipated, $\alpha=0.86$. Hence, all alpha levels met the desired $\alpha=0.70$ level needed (Gliem \& Gliem, 2003).

Second, to evaluate performance across students' writing samples, a level of abstraction scale was utilized as per Applebee et al. (2003) as a part of scoring students' writing products. This rubric was meant to help scorers examine types of, in this case, student writing completed as per how students approach such writing assignments. The second portion of the writing rubric is the level of elaboration scale, also developed by Applebee et al. (2003), which reviews the depth of support the student uses within their writing as well as their organization. The Applebee et al. (2003) scale was originally used by the National Assessment of Educational Progress (NAEP); hence, it has been externally vetted and validated, and the scale is meant to give credit for the overall level of difficulty of the writing task and the student's success in completing it. In addition to these two categories on the writing rubric, scorers evaluated student voice in the writing using a 
modified rubric based on the six traits (Burke, 2014). Overall, the scales range from either a score of 1-4 (Level of Elaboration) or a scale of 1-5 (Level of Abstraction and Voice) with the highest scores representing those most desired. This leaves each student's writing product with a possible total of 14 points with more points meaning that the students were demonstrably stronger writers, in these three areas, on this given task. (See the "Writing Rubric" in Appendix E.)

In order to achieve internal consistency between raters (i.e., inter-rater reliability), two independent coders scored all students' writing assignments, and any discrepancies between the two graders were averaged. The coders were pre-service secondary English teachers, and were trained prior to scoring on the appropriate application of the rubric using other essays pulled from outside the direct samples collected in this study. These scorers scored all students' essays blindly, whereas they did not know to which group (i.e. YA or canonical) each student belonged. The hypothesis tested here was whether the students who read the YA literature story had a stronger voice or were able to elaborate or develop a stronger analysis of the prompt, as compared to the students in the canonical group.

Once all the scores were in, they were used to compare students' writing results. Each students' by-assessment construct and total scores were inputted into a spreadsheet, the mean scores were calculated and standard deviations for each group separately computed, and finally the scores were statistically assessed to determine if there was indeed a mean score difference between the two sets of students (i.e., YA or canonical). This process assumes, again, that the YA students' writing scores would be significantly higher than those who were not exposed to the YA literature, although the YA students were lower achievers from the beginning. Nonetheless, the goal here was not to analyze growth in writing over time, but merely to what extent, if any, students who engaged with YA literature wrote any better in sum or in any regard, than their arguably dissimilar and higher achieving peers.

Third, using audio recordings from all twelve of the individual student interviews and the one teacher interview, data were transcribed verbatim for further qualitative analyses. Once all data were transcribed, they were coded as per the approach discussed in Suter (2011), looking for patterns throughout the interviews to generate minor and major themes, and also to supplement findings from the pre/post tests and surveys to gain further insights into the students' perceptions of both the short stories they read as well as their thoughts about the writing assignments following the readings given the short stories they read (Suter, 2011). 
In terms of the teacher interview, it was of particular interest to note whether the students and teacher had similar perceptions concerning the different short stories students read. Of particular note was supplementary information that added value to the students' responses, and that would also help explain some of the minor and major themes that emerged given all sets of data analyses focused on students in this study. Additional or important ideas in terms of context were also noted as in, for example, how students might have impacted the study given the differential groups or how other factors and variables unknown might have also impacted the findings of the study.

\section{FINDINGS}

The findings generated information concerning the Student Self Report survey changes for the students in terms of the canonical group compared to the YA group, as well as the overall writing sample scores for both the YA and canonical groups. The student interviews also generated indepth information regarding each groups' perception of the project itself as well as their thought processes behind both the reading they did in class as well as the writing prompt to which they responded in writing after the reading. The teacher interview allowed the subject teacher to explain her thoughts about each piece of literature read, her perception of the students' attitude towards the texts, and her perception of the students' writing process.

\section{YA VERSUS CANONICAL GROUP MEAN DIFFERENCES ON WRITING}

\section{APPREHENSION}

The first level of analysis completed looked at the mean scores for the changes on the Student Self Report survey from the pre- to post-test. The canonical group and the YA group did display a difference in the means. The YA group gained more than the canonical group, who actually responded less favorably in terms of their responses concerning their apprehension towards writing; although, the difference between both groups was not statistically significant $(p<.05)$. More specifically, when comparing the means for all four classes, the canonical groups demonstrated a mean score change of -1.59 , which indicates that their overall apprehension towards writing increased, since a higher score demonstrates less writing apprehension; however, the student selfreport score for the YA groups demonstrated a positive gain with a mean gain score of 0.23. Again, however, these scores were not statistically significant $(p<.05)$, and this was likely due to a 
relatively small sample size $(N=88)$, and also some of the findings that came out during the qualitative analyses, forthcoming.

\section{YA VERSUS CANONICAL GROUP MEAN DIFFERENCES ON STUDENT WRITING SAMPLES}

In terms of the differences between YA and canonical group students on their writing samples, students in the YA group outscored their peers from the canonical group on "levels of abstraction" (mean difference $=0.16, p=.96$ ), "levels of elaboration" (mean difference $=0.06, p=.09$ ), and "voice" (mean difference $=0.07, p=.08$ ) which also resulted in a greater total score for the YA group (mean difference $=0.30, p=.22$ ). None of these differences was statistically significant, either, although it is interesting to note that the students who were identified by the teacher as being lower performers actually outscored the canonical group students who were identified as average or above average by the teacher. Although this study was employed in the hopes that the YA group would exhibit stronger writing skills, this possibility had to be discounted once classes chosen by the teacher to read the YA were lower-level performers. Discovering that the students did actually outperform the canonical, higher-achieving group, even though it would have been considered unlikely, was an exciting discovery and definitely warrants further examination. In evaluating the student and teacher interviews, the common thread throughout the interviews also supports the idea that the approach utilized for this study was effective, particularly for the types of students in the YA group.

\section{STUDENT THOUGHTS ON READINGS}

The students who were interviewed concerning the story and subsequent writing assignment had similar sentiments about the story itself regardless of which story they read. Multiple students who read the "Harrison Bergeron" piece identified the story as being "different," "futuristic," and "weird." The idea that the story was different from anything they had read before was a common thread throughout all the interviews, which demonstrated an unintended novelty effect (a reaction due to something different as opposed to the actual treatment) for the pieces. Due to this novelty effect, there was not a significant difference regarding the students' initial reaction to either story as both groups found them unique and "better" than what they had read previously. What was interesting, however, was the idea that the YA group of students who read "Last Book in the 
Universe" identified more strongly with the idea that the story seemed more "realistic" and could potentially represent the future. One student stated that it was really "interesting to see how the world will be way down the line.”

When asked how the students felt about the story, the students in the canonical group gave straight forward answers including, "it was okay," "it was different," “interesting," or "don't know." When attempting to extract the responses for the same question with students from the YA group, however, there was a great deal more discussion about the actual story itself and what it might mean to each student. For example, one student stated, "I hope it doesn't happen," and another student said that it was, "scary and interesting but I liked it." Another student responded to this question by discussing how people were "too into technology" and continued with this train of thought into our current overuse of technology. The variety of responses and personal connection with the story may indicate a higher level of involvement with the text itself on behalf of the students. Accordingly, the canonical group specifically referenced the text a total of eight times in the interview while the YA group specifically referenced their text a total of 12 times.

\section{THOUGHTS CONCERNING THE WRITING TASK}

When the students were asked about how easy it was to write the essay after reading the story, there was a notable increase in positive responses from the YA group. Knowing that the students for both YA groups were considered to perform at a lower level by the teacher, this is an important distinction to make between the classes, since the students who participated in the YA group also had a lower mean score on the student self-report survey overall as compared to the canonical group. The students seemed to equate the knowledge or familiarity with the story as an important indicator of their readiness to write the essay. The canonical group students made comments such as "didn't know what to put” and “different because I didn’t know what to put.” Another student reported that he did not feel ready to write because he was not sure about the story, although several others did state that the story was easy. The YA group students, on the other hand, unanimously reported that the essay was easy. This is interesting because these students had a lower mean on the modified Daly-Miller Writing Apprehension test. According to the interpretation of the apprehension survey test results, the YA group demonstrated less comfort with writing in general; however, with this particular writing prompt applied to "The Last Book in the Universe," at least, they expressed a higher level of comfort than the canonical group. The 
types of comments made by the YA group regarding the ease of the writing assessment included that it was "easy because the story was interesting to read and, like, write about." Another student said that she was comfortable writing the essay because she understood the story and also commented that more details in the story made it easier to write about the prompt.

\section{Ability to Generate IDEAS FOR THE PROMPT}

As the essay prompt was based on technology and its impact on humanity, it was possible to write the essay without using or referencing the story in any way, so the story itself may not have had an impact on students' ability to generate ideas for the essay prompt. Hence, the majority of the students who were part of the canonical group reported that it was easy to come up with ideas for this essay, although they reported a greater level of difficulty with the writing prompt in the previous question. In several instances, the students indicated the subject matter (technology) as being the reason for their abundant ideas, and several students also made mention of the fact that this essay was much different than any other essay they had written before simply because of the topic they were assigned. One student commented that he had already been thinking about the topic he wrote about prior to reading the story, even. Several students, however, did say that they felt a need to understand the story before they could begin writing. The YA group students collectively indicated that they found it easy to come up with ideas also. One interesting reason given by a student for finding it easy to come up with ideas was when he said, "All the things are happening in the real world.” Even though both pieces were futuristic and had a dystopian theme, the idea that the YA literature piece was more "realistic" actually came through several times throughout the interviews. This sense of writing about reality may have contributed to the students' ability to come up with ideas more readily, although one might wonder what causes students to see this highly futuristic idea as more realistic than the other story, which actually has less technology.

\section{SELF-PERCEPTION AS WRITERS}

When members of the canonical group of students were asked if they felt they were good writers, only one of them self-reported as being good at writing, while the others positioned themselves as somewhere in between good and bad writers. The YA students shared somewhat similar qualities; however, one student identified himself definitively as a bad writer, while the other students were more ambivalent. One YA student did state that, "writing is not really easy for me, but this was 
easy." These reports are in keeping with the numbers of students who self-reported whether they were strong writers on the demographic portion of the writing apprehension survey, where 62/87 (71\%) students said they were not strong writers and 25/87 (29\%) students said they were strong writers. Again, it is important to note that the teacher selected academically stronger groups for the canon and academically weaker for YA, such that results were likely to be skewed.

\section{STUdent View of TeChNology Post Reading}

The final theme that developed throughout the student interviews was the student view of technology. Students were asked whether they saw technology differently after reading the short story, and the similarities between the canonical group and YA group were very high. In each group of students, four of the six (66\%) students simply stated that they saw technology differently after reading the story than they had before. In the canonical group, the remaining two (33\%) students did note that they now saw technology as being potentially bad, or controlling in some way. In the YA group, the remaining two students commented on how technology may actually be approaching the advanced level seen in the story already. The core concept of both texts seemed to be understood at a similar level for both sets of students.

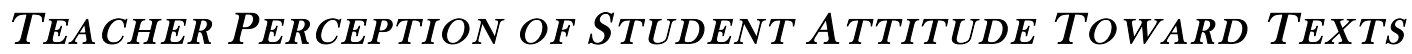

When discussing the project, the teacher reported that she really enjoyed teaching the pieces and intends to use them with her classes for the following year. The observations that she made with teaching the text, however, did not fully reflect the way the students perceived the project. The teacher was concerned that the students would struggle with the slang present in the YA piece ahead of time, and she felt as if her concerns were validated. She confessed that she spent an inordinate amount of time on close reading, and she was concerned that it would cause the students to not like the story because they might be overly focused on all of the things they have to do for close reading. In other words, enjoying the reading may not have been "first and foremost" for the students. This is an interesting statement about the emphasis of standardized tests upon the motivations of this particular teacher, and warrants further investigation.

When asked about how the students responded to each piece, the teacher lamented her decision to give the higher achieving students the "Harrison Bergeron" piece while giving her other students the "Last Book in the Universe" because she felt as if she skewed the research in some 
way. She noted that her better performing students "got 'Harrison"” however, they were just more likely to enjoy reading in general. She did, however, believe that her other classes, which had "The Last Book in the Universe" liked the story. The teacher also commented on the relative ease of reading the pieces since the students did not seem to struggle or have as many questions about the meaning of the texts as they had for previous short stories they have read. Upon further reflection, she did remember that there were two sections within each piece that posed comprehension problems for the students, and she had to re-visit those areas for each group.

\section{TEACHER PERCEPTION OF STUDENT WRITING BEHAVIORS}

The students' writing behaviors were the most surprising for the teacher. She stated:

I was pleasantly surprised, because I gave them max 25 minutes, and I was pleasantly surprised that pretty much most of them were able to get three paragraphs. They wrote the whole time, so they had something to write from right away. ... Everybody was writing. Normally I'd have to walk around and get a couple of kids individually to get started.

This coincides with the responses given by students in the interviews as they discussed having an easier time in terms of their ability to write the essay and their ability to produce ideas, abilities more prevalent among the YA group students.

\section{TEACHER ATTITUDE TOWARD TEXTS}

When asked about how she personally felt about teaching the two different pieces, the teacher admitted to "actually keeping [the stories] because [she] thinks [she'll] probably use them next year." When asked why, she answered, "The stories we teach currently don't resonate with the students." While she had always known that the students didn't like to read in her classroom, the realization that it may have been the literature being assigned as opposed to the students' own shortcomings was significant. In terms of changes that she would make for her own purposes, the primary difference would be that she would have all of her students read both stories since she saw value in both texts. This, again, supports the students' thoughts about each text, whereas they noted that they were different from anything else they had read and they held more "realistic" qualities. Additionally, having the students read both pieces would be an interesting study, and one that may more specifically isolate YA literature. 


\section{IMPLICATIONS}

With the current emphasis on instructional shifts such as increased rigor introduced with the onset of the National Common Core Standards and the parallel in higher Lexile level expectations, the type of literature students are often asked to read is most often canonical and reminiscent of the reading done by students for decades prior, yet students who struggle with reading and writing in general may not do well with these types of literatures (Alvermann, 2007; Gordon, 2010; Guthrie, Wigfield, \& You, 2012). Utilizing contemporary literature that resonates with students can prove to be helpful to both the teachers and the students for their growth and development, and the findings demonstrate that YA literature can serve this purpose (Appleman, 2007; Lesesne, 2007). Furthermore, these findings demonstrate that students may not only experience emotional and psychological growth as they read and identify with the YA literature used in class, but they may also experience growth in terms of their perceived ability to write. One interesting development is the significant improvement in writing apprehension score for the YA class that had a relatively large percentage (35\%) of special education students. Writing apprehension can be a mitigating factor in hindering student success (J. Daly, 1978; Pajares, 2003).

Students who are identified as special education, or as struggling students, often carry with them an inherent belief in their inability to succeed in various academic endeavors. In order for this to change, we must help students view themselves in a different intellectual light. Graham’s Effective Writing Instruction for all Students (2008) recommends “[f]oster[ing] students' interest, enjoyment, and motivation to write." (p. 2). One way in which to do this is to help students develop a "can do" attitude towards writing, and this study demonstrates that the reading of YA literature helped several students see this writing, at least, as "easy". Allowing these lower-achieving students to read books that focus on things they consider "real," in addition to incorporating language that may be used by their peer group, resulted in an improvement in the students' feelings about writing. It makes sense, then, that we utilize these types of literature in the classroom to assist in developing a positive self-perception of students' writing ability (Applebee et al., 2003; Applebee \& Langer, 2011). Self-efficacy (Moley, Bandré, \& George, 2011; Pajares, 2003) is certainly a powerful component of student learning, and the idea that students could gain this self-efficacy from reading YA was reinforced in this study. 
It is also interesting to note that the core "content" of each piece was equally well received by all of the students, so if we assume that students are supposed to learn a grander theme from literature, it may not be crucial that we all read the same text in order to get the big picture message. The current trend within standardized education purports to allow teachers to develop their own curriculum in ways that address the standards, and this study demonstrates that a student's increased use of textual evidence and the ability to think critically can be generated from non-canonical texts, and, in fact, may be more effective. Additionally, teachers who are attempting to teach to larger classes with a wider range of abilities in the classroom would benefit from the addition of literature that students enjoy.

The fact that the students within the YA groups demonstrated stronger writing on this particular task may indicate that there is some empirical merit to utilizing YA literature, particularly with students who do struggle with reading and writing, generally speaking. While the evidence is clear that students tend to see themselves in YA literature, which may directly benefit their growth as individuals, there is little work to legitimize the importance of literature students connect with and its subsequent impact on other forms of academics. With the current educational climate inundated with the need to provide tangible evidence of effectiveness, it is increasingly important that educators and researchers begin do the work of providing this evidence to policy makers so that our students do not pay the price of reform.

\section{STUDY Limitations}

Having the teacher select which classes would become the YA group created an imbalance in student base ability levels and perhaps potential and aptitude for growth. Although this resulted in interesting findings, it would be useful to replicate this study with a more balanced sample set of students in terms of academic and achievement levels. Working with a teacher who felt her students might benefit from YA literature was important, but created significant problems with the generalization of this study because of the teacher's desire to make the study find what the researcher was hoping for. The novelty effect of both pieces of literature was also a surprise to me, and it would be of interest to know if the students would have responded differently if the type of literature they studied was more similar to the pieces to which they are more normally accustomed in school in order to further isolate whether the YA literature was the cause of the positive impact on the writing apprehension scores and writing sample scores. Additionally, the writing sample was 
intended to be constant, but the difference in setting within the stories may have lead the students to a more significant level of differences in terms of their levels of elaboration as it related to their textual reference.

\section{NEXT STEPS}

There is certainly a need for this or similar examinations to be replicated, and choosing pieces that are either more significantly different or more evenly consistent (i.e. in terms of setting) might help to isolate the impact of the YA literature on the students, as well as student products. The future researcher should consider the types of reading and writing already being done by students in order to avoid the novelty effect experienced here. Additionally, the writing prompt ought to be carefully considered in terms of any potential guidance or direction built in to the question. It would also be useful to be more purposeful about randomizing the groups of students who read each type of literature as well as those students who were interviewed at the end of the process in order to gain a more generalizable study. Ensuring that varied levels of students read the YA pieces would be beneficial as well, in order to ascertain whether YA literature would be motivational and/or helpful to all students equally. Additionally, completing this study on a broader scale with more teachers who may be less pre-disposed to the benefits of YA literature may get at a more clear understanding of impact on writing reading YA could have on students.

\section{CONCLUSiON}

One goal of this study was to ascertain whether students' aptitude and attitude in regard to writing would improve with the utilization of YA literature as a catalyst. As Appleman (2007) wrote, reading YA literature can help students to make discoveries about both themselves and the world around them. These types of knowledge are necessary components in writing. This mixed methods study demonstrated that relevant literature does facilitate increased learning as posited by Alvermann (2007), Beers (2007), Ivey and Broaddus (2001) and Keene (2007). The students also demonstrated a connection to the literature itself, which ultimately manifested in an improved attitude toward writing as well as stronger writing samples.

The results from this study were noteworthy in that students who were assumed, and also identified by the teacher, to perform at a lower level demonstrated improved writing attitude at a greater rate than other students, and, more importantly, wrote essays that had an overall higher 
mean score according to independent scorers who had no pre-conceived notions about the students. Accordingly, the teacher's perception of the project and her excitement over the student reaction to both the reading and writing indicates that this may be a valuable approach for teachers of students who struggle with more canonical forms of texts. The most important component of this research, however, is the student perception of how easy it was to write after the YA literature piece. This finding alone warrants further research to isolate the impact of the YA literature on various writing genres.

\section{REFERENCES}

Alsup, J. (2013). Teaching literature in an age of text complexity. Journal of Adolescent and Adult Literacy, 57(November), 181-184. doi:(0.1002/JAAL.239

Alvermann, D. (2007). Multiliterate youth in the time of scientific reading instruction. In K. Beers, R. Probst, \& L. Rief (Eds.), Adolescent literacy turning promise into practice (pp. 19-26). Portsmouth: Heinemann.

Angelotti, M. (1984). O.K. if YA lit is so good, why can’t I sell it in my school? The English Journal, 73(7), 73-75. doi:129.219.247.33

Applebee, A. N., \& Langer, J. A. (2011). EJ extra: A snapshot of writing instruction in middle schools and high schools. English Journal, 100(6), 14-27.

Applebee, A. N., Langer, J. A., Nystrand, M., \& Gamoran, A. (2003). Discussion-based approaches to developing understanding: Classroom instruction and student performance in middle and high school English. American Educational Research Journal, 40(3), 685-730. doi:http://dx.doi.org/10.3102/00028312040003685

Appleman, D. (2007). Reading with adolescents. In K. Beers, R. Probst, \& L. Rief (Eds.), Adolescent literacy turning promise into practice (pp. 143-147). Portsmouth: Heinemann.

Beers, K. (2007). The measure of our success. In K. Beers, R. Probst, \& L. Rief (Eds.), Adolescent literacy turning promise into practice (pp. 1-14). Portsmouth: Heinemann.

Beumer Johnson, A. (2011). Multiple selves and multiple sites of influence: Perceptions of young adult literature in the classroom. Theory into practice, 50(3), 215-222. doi:10.1080/00405841.2011.584032

Bickmore, S., \& Emiraliyeva-Pitre, L. (2013). Teaching diverse young adult literature in harmony with the common core state standards: Is it still just about the characters, the plot, the setting? 
SIGNAL, 1-6.

Burke, J. (2007). Teaching English language arts in a "flat" world. In K. Beers, R. Probst, \& L. Rief (Eds.), Adolescent literacy turning promise into practice (p. 149). Portsmouth: Heinemann.

Cazden, C., Cope, B., Fairclough, N., Gee, J., \& Al., E. (1996). A pedagogy of multiliteracies : Designing social futures. Harvard Educational Review, 66(I), 60-92.

Connors, S. P. (2012). Becoming mockingjays: Encouraging student activism through the study of YA dystopia. The ALAN Review. Retrieved from http://scholar.lib.vt.edu/ejournals/ALAN/

Creswell, J., \& Clark, V. (2010). Introducing a mixed methods study. In Designing and conducting mixed methodsrResearch (2nd ed., pp. 143-170). Thousand Oaks, London, Singapore and New Delhi: SAGE Publications.

Cronbach, L. J. (1951). Coefficient alpha and the internal structure of tests. Psychometrika, 16, 297-334. doi:10.1007/BF02310555

Daly, J. (1978). Writing apprehension: Writing competency. The Journal of Educational Research, 72(1), 10-14. Retrieved from http://www.jstor.org/stable/27537168

Daly, J. A., \& Wilson, D. A. (2016). Writing apprehension, self-esteem, and personality. Research in the Teaching of English, 17(4), 327-341. Retrieved from http://www.jstor.org/stable/40170968

Daly, J., \& Miller, M. (1975). The Daly-Miller test interpretation. Retrieved from http://www.csus.edu/indiv/s/stonerm/daly_miller_scoring.htm

Freedman, L., \& Johnson, H. (2000). Who's protecting whom? "I hadn't meant to tell you this", a case in point in confronting self-censorship in the choice of young adult literature. Journal of Adolescent \& Adult Literacy, 44(4), 356-369. doi:129.219.247.33

Gee, J. P. (2010). A situated sociocultural approach to literacy and technology.

Glenn, W., Ginsberg, R., Gaffey, E., Lund, K., \& Meagher, I. (2012). From awareness to action: Young adult literature as a road to reflection and catalyst for change. The ALAN Review, $39(2)$.

Gliem, J. A., \& Gliem, R. R. (2003). Calculating, interpreting, and reporting Cronbach's alpha reliability coefficient for Likert-type scales. In 2003 Midwest Research to Practice Conference in Adult, Continuing, and Community Education (pp. 82-88).

Goering, C. Z., \& Connors, S. P. (2014). Exemplars and epitaphs : Defending young adult literature. Talking Points, 25(2), 15-21. 
Gordon, C. (2010). Meeting readers where they are: Mapping the intersection of research and practice. School Library Journal, 56(11), 32.

Graham, S. (2008). Effective writing instruction for all students. Wisconsin Rapids.

Guthrie, J. T., Wigfield, A., \& You, W. (2012). Instructional contexts for engagement and achievement in reading. In S. L. Christenson (Ed.), Handbook of research on student engagement (pp. 601-634). SpringerUS. doi:10.1007/978-1-4614-2018-7_29

Hayn, J. A., Kaplan, J. S., \& Nolen, A. (2011). Young adult literature research in the 21st century. Theory Into Practice, 50(3), 176-181. doi:10.1080/00405841.2011.584026

Hayn, J., Kaplan, J., \& Nolen, A. (2016). Teaching young adult literature: Integrating, implementing, and re-imagining the common core. (J. Hayn, J. Kaplan, A. Nolen, \& H. Olvey, Eds.). Lanham and London: Rowman \& Littlefield Publisher, Inc.

Hinton, K., \& Rodriguez, R. J. (2014). "I was carrying the burden of my race": reading matters of race and hope in YA literature by Walter Dean Myers and Sherman Alexie. In C. Hill (Ed.), The critical merits of young adult literature (pp. 92-111). New York: Routledge.

Hunt, C. (1996). Young adult literature evades the theorists. Children's Literature Association Quarterly, 21(1), 4-11. doi:10.1353/chq.0.1129

Ivey, G., \& Broaddus, K. (2001). "Just plain reading" : A survey of what makes students want to read in middle school classrooms. Reading Research Quarterly, 36(4), 350-377.

Keene, E. (2007). The essence of understanding. In K. Beers, R. Probst, \& L. Rief (Eds.), Adolescent literacy turning promise into practice (pp. 27-38). Portsmouth: Heinemann.

Kober, N., \& Retner, D. (2011). Common core state standards: Progress and challenges in school districts' implementation. Retrieved from http://www.cepdc.org/displayDocument.cfm?DocumentID=374

Langer, J. A. (1986). A sociocognitive perspective on literacy. Viewpoints. Stanford.

Langer, J. A. (2013). The role of literature and literary reasoning in English language arts and English classrooms. In K. Goodman, R. Calfee, \& Y. Goodman (Eds.), Whose knowledge counts in government literacy policies (pp. 161-166). New York: Routledge. doi:http://dx.doi.org/10.4324/9780203796849

Lesesne, T. (2007). Of times, teens, and books. In K. Beers, R. Probst, \& L. Rief (Eds.), Adolescent literacy turning promise into practice (pp. 61-79). Portsmouth: Heinemann.

Lewis, M., \& Durand, E. S. (2014). Sexuality as risk and resistance in young adult literature. In C. 
Hill (Ed.), The critical merits of young adult literature (1st ed., pp. 38-54). New York: Routledge.

Malo-Juvera, V. (2014). Speak : The effect of literary instruction on adolescents' rape myth acceptance. Research in the Teaching of English, 48(4), 407-427.

Moley, P. F., Bandré, P. E., \& George, J. E. (2011). Moving beyond readability: considering choice, motivation and learner engagement. Theory Into Practice, 50(3), 247-253. doi:10.1080/00405841.2011.584036

Monroe, M. L. (2005). Writing with Weetzie : Using young adult literature in the composition classroom. Language Arts Journal of Michigan, 21(2), 48-54. doi:10.9707/2168-149x.1199

Moore, D., Bean, T. W., Birdyshaw, D., \& Rycik, J. A. (1999). Adolescent literacy: A position statement. Journal of Adolescent \& Adult Literacy, 43(1), 97-112. doi:129.219.247.33

Pajares, F. (2003). Self-efficacy beliefs, motivation, and achievement in writing: A review of the literature. Reading \& Writing Quarterly, 19(2), 139-158. doi:10.1080/10573560308222

Philbrick, R. (1999). Last Book in the Universe. In M. Cart (Ed.), Tomorrowland: 10 Stories about the Future. Scholastic.

Shanahan, T., \& Duffett, A. (2013). Common core in the schools: A first look at reading assignments. Retrieved from http://edexcellence.net/publications/common-core-in-the-schools

Stotsky, S. (2010). Literary study in grades 9, 10, and 11: A national survey. Forum.

Stotsky, S. (2014). Common core standards' devastating impact on literary study and analytical thinking. Retrieved from http://www.heritage.org/research/reports/2012/12/questionablequality-of-the-common-core-english-language-arts-standards

Stover, L., \& Bach, J. (2011). Young adult literature as a call to social activism. In J. A. Hayn \& J. S. Kaplan (Eds.), Teaching young adult literature: Insights, considerations, and perspectives for the classroom teacher (1st ed., pp. 203-222). Lanham, Boulder, New York, Toronto, Plymouth, UK: Rowman \& Littlefield Publisher, Inc.

Suter, W. N. (2011). Qualitative data, analysis, and design. In Introduction to educational research: A critical thinking approach (Second, pp. 342-386). SAGE Publications.

Thompson, K. H. (2014). Beyond the stacks: Why high school English teachers should be talking about books. English Journal, 103(6), 38-44.

Wolk, S. (2009). Reading for a better world: Teaching for social responsibility with young adult literature. Journal of Adolescent \& Adult Literacy, 52(May), 664-673. 
doi:10.1598/JAAL.52.8.2

AlicE HAYS is a PhD. student in the Department of English Education at Arizona State University. She can be contacted at alice.hays@asu.edu. 


\section{Appendix A}

\section{Student Self-Report Survey}

Name

Gender:

Male Female

What is your ethnicity? Latino/a White/Anglo African American Asian Other

Current Grade Point Average (GPA) Current English grade

What is your first language?

What is the language most often spoken at home?

Do you feel you are a strong writer? YES NO

This survey is meant to assess how you feel about writing.

Please respond to each statement given the extent to which you agree with each of the following statements. Please use the following scale: Strongly Agree (SA), Agree (A), Neutral (N), Disagree (D), or Strongly Disagree (SD).

\begin{tabular}{|c|c|c|c|c|c|}
\hline & $\begin{array}{l}\text { Strongly } \\
\text { Agree }\end{array}$ & Agree & Neutra & Disagree & $\begin{array}{l}\text { Strongly } \\
\text { Disagree }\end{array}$ \\
\hline 1. I avoid writing & $\mathrm{SA}$ & A & $\mathrm{N}$ & $\mathrm{D}$ & SD \\
\hline 2. I am not afraid of my writing getting graded. & & & & & \\
\hline 3. I look forward to writing down my ideas & & & & & \\
\hline $\begin{array}{l}\text { 4. I am afraid of writing essays because I know } \\
\text { they will get graded }\end{array}$ & & & & & \\
\hline 5. Taking a writing class is a scary experience. & & & & & \\
\hline 6. Handing in an essay makes me feel good. & & & & & \\
\hline $\begin{array}{l}\text { 7. My mind seems to go blank when I start to } \\
\text { work on my essay. }\end{array}$ & & & & & \\
\hline $\begin{array}{l}\text { 8. Expressing ideas through writing seems to } \\
\text { be a waste of time. }\end{array}$ & & & & & \\
\hline $\begin{array}{l}\text { 9. I would enjoy turning my writing into } \\
\text { magazines to get reviewed and published }\end{array}$ & & & & & \\
\hline 10. I like to write down my ideas. & & & & & \\
\hline $\begin{array}{l}\text { 11. I feel confident in my ability to express my } \\
\text { ideas clearly in writing. }\end{array}$ & & & & & \\
\hline $\begin{array}{l}\text { 12. I like to have friends read what I have } \\
\text { written }\end{array}$ & & & & & \\
\hline 13. I am nervous about writing. & & & & & \\
\hline 14. People seem to enjoy what I write. & & & & & \\
\hline 15. I enjoy writing. & & & & & \\
\hline $\begin{array}{l}\text { 16. I never seem to be able to write my ideas } \\
\text { down clearly. }\end{array}$ & & & & & \\
\hline
\end{tabular}




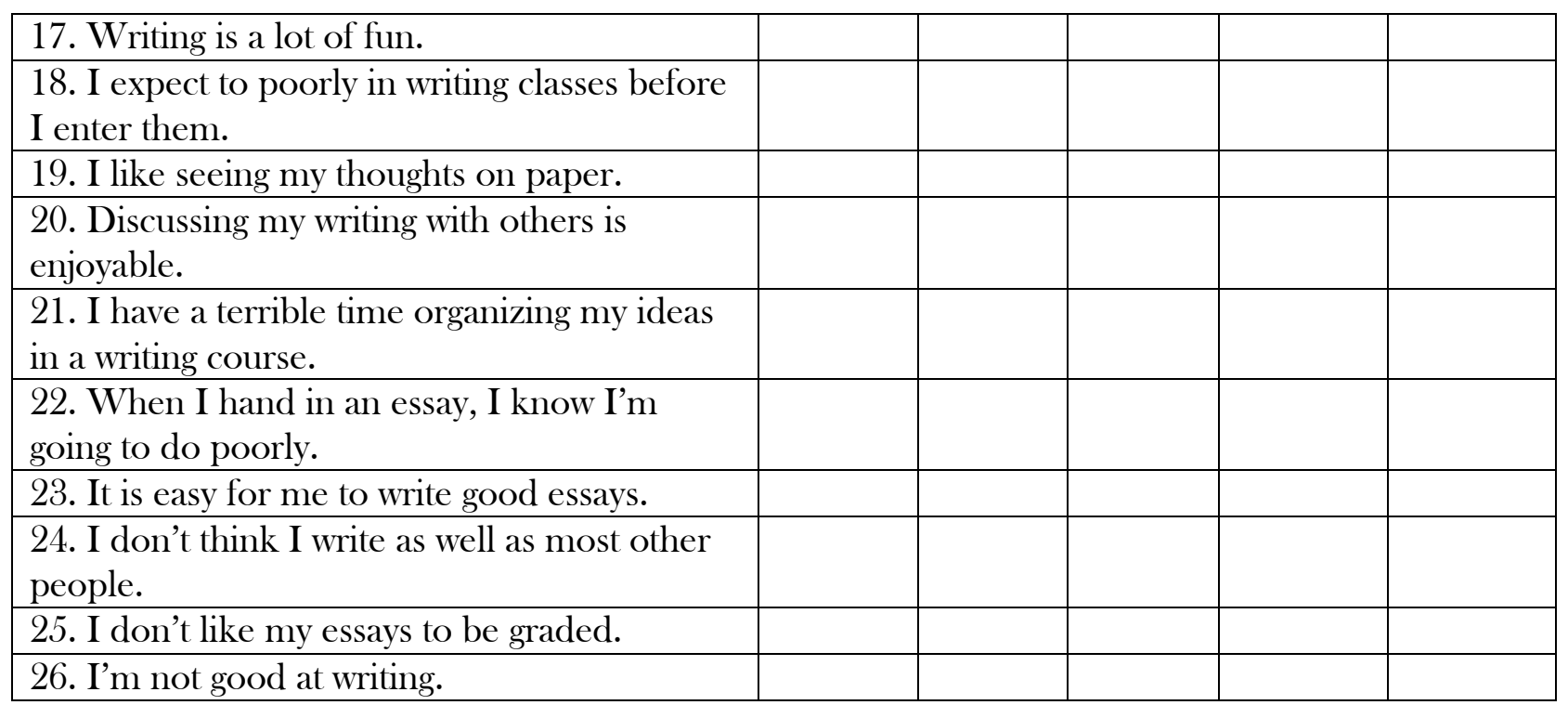




\section{Appendix B}

"Student Writing Prompt”

Potential Classroom Discussion questions:

How does technology show up in this piece?

How are people controlled by the technology?

Are people happier with this technology? Why or why not?

Is this something that you could imagine happening in our society?

Writing Prompt \#1

Science Fiction is often thought to be the harbinger (fortune-teller) of truth in some ways.

Using your prior knowledge and experience, as well as the short story you just read, discuss what role technology plays in de-humanizing people. De-humanizing is defined as making someone stop feeling or behaving as normal people. Can technology make society "less human" somehow? If you disagree with this idea, you may write about that instead. Think about your personal experiences with this as well as the short story you read yesterday. This assignment should be a minimum of three paragraphs.

This will be written in class. You may use any resources readily available to you, including the text read in class yesterday. 


\section{Appendix C}

"Student Interview Protocol"

1.) How did you feel about the short story that you read?

2.) How did the reading of that short story seem different from other stories you've read in your class in the past this year?

3.) How did you feel about writing this essay after reading the short story?

4.) What is the difference in your writing for this piece as compared to the other types of writing you have done in this class?

5.) Was it easy to come up with ideas for this writing assignment? Or perhaps easier than before?

6.) Did you use parts of the short story to make your argument? Why or why not?

7.) Do you feel like you have a different understanding of technology, or maybe a different outlook on technology than you did before reading this piece?

8.) How do you feel you are as a writer? Do you feel like this changed given the type of book you read, this time?

9.) What techniques or strategies do you use when you are writing? Do you feel like any of these strategies might have changed after reading this type of book this time?

10.) Is there anything else that you can think of that might help me understand what you thought about when you were writing this assignment? If so, please explain. 


\section{Appendix D}

“Teacher Interview Protocol”

1. What observations did you make while teaching the Young Adult Literature versus the canonical text?

2. Did students seem to respond differently to either piece? If so, how?

3. Did you notice anything different in the students' reading behaviors, in particular, given the two different groups?

4. Did you notice anything different in the students' writing behaviors, in particular, given the two different groups?

5. Did you notice anything different in the students' levels of engagement, in particular, given the two different groups?

6. What about in terms of their discussions in class?

7. How did you feel, professionally, about teaching the two different pieces and their respective values?

8. Were there any surprises?

9. What about disappointments?

10. If there is anything else you'd like to share about this study, your participation in this study, or your students' involvement, please do so now. 


\section{Appendix E}

"Writing Rubric"

Level of Abstraction

( $=$ Generalization without any development; or report or generalization with irrelevant information; or writing sample that does not answer the question.

$1=$ Record (as in a lab notebook): What's happening.

2=Report: The writer gives an account of a particular series of events or thoughts or feelings (i.e. a narrative): What happened?

3=Generalization, generalized narrative, or descriptive information (including descriptions of physical features, activities, and cognitive experiences). The writer is tied to particular events and places but detects a pattern of repetition in them and expresses the pattern in general form: What seems to be happening?

4=Low-level analysis: The writer makes genuine analyses, but organization is loose and relationships between and among points are not perceived and/or not made explicit. Major points in the text might be shuffled without altering the meaning or effectiveness of the text.

$5=$ Analysis: The writer relates points hierarchically or logically by means of coherently presented classificatory utterances (e.g. thesis statements, topic sentences, transitional expressions), producing a highly wrought text.

\section{Level of Elaboration}

1 = Unsatisfactory: The writer provides only the barest information, misinformation or disjointed details.

2 = Minimal: The writer provides some details but in unrelated ways. No organizational framework is created for the reader to use in understanding how the various pieces of information in the sample relate to each other. Major points in the text might be shuffled without altering the meaning of the text. This category includes texts that are organized merely by indicators such as "First,"'Second,"'Third,"and "Finally."

3 = Adequate: The writer describes and interrelates most of the information and presents details within a clear, coherent (although perhaps implicit) organizing framework.

$4=$ Elaborated- The writer composes an extended description within a cohesive and explicit organizing framework to provide a context for the reader. The meaning or effectiveness of the text would be altered if the order of points were disturbed. The text is highly wrought and tightly organized.

Voice

$1=$ Writer is indifferent, distanced from topic/audience; the author sounds monotone, flat or even 
bored; expository writing lacks any commitment; narrative writing shows no attempt at voice.

2=Writing may seem mechanical and the voice may be inappropriate or non-existent. Expository writing is not committed and narrative writing does not demonstrate any sense of the personal.

$3=$ Writing seems sincere but not engaged; it's plain; there is a limited awareness of audience; expository writing shows minimal commitment and narrative writing is sincere but plain.

$4=$ Writing that is appropriate to audience and purpose; the writer behind the words comes through the writing. Expository writing is somewhat persuasive and committed while narrative writing is honest but may not be engaging.

$5=$ Writing that is compelling, engaging and aware of audience; author's presence is evident and powerful; expository writing is committed, persuasive and narrative writing is honest, engaging and personal. 